\title{
Behavioral antecedents of coopetition: a synthesis and measurement scale
}

Article

Accepted Version

Creative Commons: Attribution-Noncommercial-No Derivative Works 4.0

Czakon, W., Klimas, P. and Mariani, M. (2020) Behavioral antecedents of coopetition: a synthesis and measurement scale. Long Range Planning, 53 (1). 101875. ISSN 0024-6301 doi: https://doi.org/10.1016/j.Irp.2019.03.001 Available at https://centaur.reading.ac.uk/82598/

It is advisable to refer to the publisher's version if you intend to cite from the work. See Guidance on citing.

To link to this article DOI: http://dx.doi.org/10.1016/j.Irp.2019.03.001

Publisher: Elsevier

All outputs in CentAUR are protected by Intellectual Property Rights law, including copyright law. Copyright and IPR is retained by the creators or other copyright holders. Terms and conditions for use of this material are defined in the End User Agreement.

\section{www.reading.ac.uk/centaur}

\section{CentAUR}

Central Archive at the University of Reading

Reading's research outputs online 


\title{
Behavioral antecedents of coopetition: A synthesis and measurement scale
}

\begin{abstract}
This study taps into managers' perceptions of coopetition antecedents to better understand why firms adopt coopetition. By analyzing and synthesizing findings from systematic reviews of coopetition literature we integrate knowledge on coopetition antecedents. We develop and validate a scale measuring behavioral coopetition antecedents: strategic rationale and coopetition mindset. Based on a random sample of 368 Polish tourism firms, we run exploratory and confirmatory factor analyses to find that antecedents used in coopetition literature converge into two latent, behavioral constructs. Our data substantiate the view that coopetition is an intentional strategy, driven by a strategic rationale. Managers are found to pursue coopetition in order to reach clearly defined benefits with fitting partners. Moreover, three elements are found to converge in the coopetitive mindset latent construct: orientation to cooperation, trust, and experience in coopetition. We contribute to the methodological advancement of measurement instruments with applicability potential in future research examining the behavioral antecedents of coopetition. We also advance the behavioral stream of research in strategy by empirically identifying the connection between rational and behavioral antecedents of firms' coopetitive strategic behavior.
\end{abstract}

Keywords: coopetition, mindset, antecedents, scale development, tourism, behavioral.

\section{Introduction}

Coopetition is presented as a revolutionary mindset opening avenues to win-win strategic situations (Brandenburger and Nalebuff, 1996), often as the most efficient form of inter-firm relationships (Walley, 2007), and increasingly as the best strategic option (Le Roy 
and Czakon, 2016). Collaborating with competitors allows firms to pursue efficiency, access and exploit resources, create enhanced value, achieve market power and traction (Morris et al., 2007; Ritala, 2012), innovate, drive performance, and prevail in the global competition (Bouncken et al., 2015). Scholars agree that coopetition may yield benefits otherwise unavailable (Czakon, 2009; Ritala and Tidström, 2014). Yet, researchers have observed through qualitative research that certain firms within the same industry adopt coopetition more often than others (Wang and Krakover, 2008), and that the propensity to adopt coopetition varies across firms (Bouncken and Fredrich, 2016; Kylänen and Rusko, 2011). Therefore, it is of paramount importance to understand why some firms adopt it, while others don't.

So far, scholars have devoted relatively less attention to coopetition antecedents (Ghobadi and D'Ambra, 2012) than to outcomes and processes, especially within large-sample research (Bouncken and Fredrich, 2012). Prior studies are theory driven, deriving antecedents mostly from the resource-based theory of the firm (Ritala, 2012). Conceptual models propose a multi-level scrutiny of antecedents by looking at the industry, dyad, or firm levels (Dorn et al., 2016), but seldom adopt the level of the individual manager. Available conceptual considerations have only been partially explored by leveraging, at best, qualitative approaches based on single case studies (Bouncken et al. 2015). As a result, individual perceptions and behavioral bounds related to initiating or cultivating coopetition are currently confined to a black box. Therefore, we set out to fill the gap on behavioral antecedents of coopetition at individual level of analysis by addressing an unanswered research question: What do managers perceive to be the antecedents of coopetition adoption?

Systematic literature reviews have revealed that coopetition antecedents are industry specific (Czakon et al., 2014) and contextual (Bengtsson and Raza-Ullah, 2016). They may include: the degree of change, intra-industry competition, the phase of the industry life-cycle, and the existence and power of regulatory bodies (Dorn et al., 2016). We control for industry- 
specific features by situating our study within a specific industry: the tourism industry. This industry is considered to be a suitable context to generate coopetition for several reasons (ChimMiki and Batista-Canino, 2017). Tourism firms build complex and dense networks (Baggio, 2011), and also exploit multiple interdependencies between firms (Björk and Virtanen, 2005) that conjointly contribute to deliver complex, modular, and integrated tourism products (Naipaul et al., 2009). Therefore, higher levels of coopetition among firms can make tourism destinations more competitive (Della Corte, Aria, 2016).

In this study, we focus on individual managers' perceptions (Abell et al., 2008; Bouncken et al., 2015) to: (a) develop a scale to measure behavioral coopetition antecedents, (b) identify two latent antecedents: strategic rationale and coopetition mindset, (c) establish the constructs' reliability, discriminant, and convergent validity, and (d) provide evidence for nomological validity of the measures. We contribute to strategic management by providing scholars with reflectively captured (Bengtsson and Kock, 2014; Luo et al., 2006) behavioral coopetition antecedents and their validated scales. In turn, the scales developed may be used, modified, and extended in future empirical research across various geographic and industry contexts, and thus foster cumulative findings that might help build and accumulate a coherent body of knowledge on coopetition strategies and their drivers.

\section{Theoretical background}

We build on the behavioral view of coopetition to explain the individual manager's cognitive underpinnings for risky decisions about coopetition adoption. Within these frameworks, we proceed by reviewing the coopetition antecedents' systematic literature reviews and extract a comprehensive list of antecedents relevant in tourism coopetition to be used as initial inventory for our measurement tool. 


\section{A behavioral view of coopetition}

Superior performance stems from the ability to overcome cognitive bounds by abandoning common ways of thinking and by seizing overlooked opportunities (Gavetti, 2012). From the behavioral perspective, a causal importance is attributed to structures and processes of cognition in the exploitation of strategy and, hence, in explaining the competitive advantage of firms (Narayanan et al., 2011). The behavioral approach to strategy views both behavioral and rational mechanisms for executing strategic choices as connected (Levinthal, 2011). We follow the central argument that how firms behave depends on what managers do, which in turn depends on what issues and answers they focus their attention on (Ocasio, 1997). The link between cognitive structures and decision processes in strategic management corresponds to strategic cognition, recently applied to study the antecedents of business models (Frankenberger and Sauer, 2018), and effective strategic issue management (Laamanen et al., 2017).

Coopetition is a game-theoretic concept that has spread in the strategy literature as a way to shape firms' strategies and achieve superior performance (Brandenburger and Nalebuff, 1996). The starting point of coopetition is a cognitive representation of the strategy problem as embedded in a value network and involving win-win situations. Engaging in coopetition involves a broader perception of actors surrounding the firm, including: suppliers, customers, complementors, and competitors. Furthermore, all involved actors can win if they both collaborate to generate more value and compete for a share in the increased "business pie," rather than competing for available value in a competitive win-lose setting (Ritala, 2012).

Coopetition complexity (Lundgren-Henriksson and Kock, 2016), tensions between the logics of collaboration and competition (Luo, 2007), and the necessity to enact environmental conditions (Mariani, 2007) pose high cognitive demands for managers. Indeed, collaboration with competitors is a source of additional risks, relating to value misappropriation, opportunistic behaviors, capability gaps, etc. (Dorn et al., 2016). Hence, managing coopetition (Le Roy et al., 
2018) is mostly seen as managing tensions (Chiambaretto et al., 2018; Fernandez et al., 2017); and firms differ in their capability to do so (Gnyawali and Park, 2011).

Those cognitive requirements are collectively termed as a "coopetitive mindset" (Brandenburger and Nalebuff, 1996; Wang and Krakover, 2008). Successful engagement in coopetition requires managers to develop a specific cognitive capacity, which entails: (a) recognizing the importance of coopetition; (b) identifying opportunities of value creation with competitors; (c) helping other managers to develop a coopetitive mindset (Gnyawali and Park, 2009). In contrast to a cognitive competence, the mindset may be considered as a habitual mental outlook that determines how one interprets and responds to situations (Gaim and Wåhlin, 2016). While the coopetition capability concept has recently been developed (Bengtsson et al., 2016), individual-level cognitive underpinnings have been left unattended both conceptually and empirically. Yet, in strategic management research the conditions of individual actions are increasingly seen as critical (Abell et al., 2008). Our study bridges this gap by exploring the coopetition antecedents from the individual manager's perspective (Walley, 2007).

\section{Coopetition antecedents}

Recent systematic coopetition literature reviews identify the question of what makes fierce competitors cooperate as one of the major themes in coopetition research (Bengtsson and Raza-Ullah, 2016). Antecedents (Dorn et al., 2016) refer to a chronological and logical precedence of a premise before an outcome, thus capturing two important features: directionality of association and causality. We use this term to capture the broadest scope of factors (Gnyawali and Park, 2009); motives and contingencies (Ritala, 2012); and drivers (Bengtsson, Raza-Ullah, 2016) that affect coopetition adoption by managers. 
The variety of terms and the diversity of relationships between antecedents and coopetition clearly denote inconsistencies in terminology and indicate a clear research gap in our understanding of what makes competitors work together (Bouncken and Fredrich, 2012). We still do not know which drivers are associated with which process and, further, which process leads to firm-level outcomes (Bengtsson et al., 2016). Nevertheless, systematic literature reviews provide a comprehensive picture of prior efforts to identify the specific sets of antecedents that can stimulate the coopetition adoption process (Table 1).

---- insert TABLE 1 about here ----

Coopetition is recognized as industry specific and contextual. Therefore, our literature analysis links systematic literature reviews on coopetition in general (Bengtsson and RazaUllah, 2016; Bouncken et al., 2015; Czakon et al., 2014; Dorn et al., 2016) to tourism-focused systematic literature reviews (Chim-Miki and Batista-Canino, 2017), in order to develop a list of items useful in a reflective empirical study of coopetition antecedents (Table 2).

--- insert TABLE 2 about here ---

Perceived benefits refers to goals, capabilities, and prospective strategies, attainable through coopetition (Bengtsson and Raza-Ullah, 2016). Firms may be pursuing market power, improved innovation output, increased value creation in supply chains, and strengthened global competitiveness (Bouncken et al., 2015). Coopetition can be used by a firm to gain a competitive advantage, by accessing needed resources, creating opportunities for cost reduction and value creation, or being more successful in strategy development, implementation and realization (Gnyawali and Park, 2009). Resource-related benefits include improving efficiency 
in resource utilization and performance increase, by leveraging a firm's own resources and linking them to the resource bases of the partners (Ritala, 2012). Among the benefits available to coopeting tourism firms, scholars list: value creation, social capital increase, enhancement of the quality of the visitor experience, co-creation of the tourist experience, economies of scale, the building of destination brands, and integration (van der Zee and Vanneste, 2015). In tourism, pooling resources for the greater good of the destination and to enhance the effectiveness of destination marketing, as well as for the creation of superior value among cooperating tourism organizations, is seen as one of the most important objectives for cooperation (Damayanti et al., 2017). The list of strategic goals identified in tourism coopetition also includes shared activities such as branding, destination marketing, knowledge creation, value co-creation, and cost reductions (Chim-Miki and Batista-Canino, 2017). Tourism products and services are complex and modular, therefore firms "have to effectively coordinate resources and capabilities between participating businesses, which require both cooperation and competition" (Wang and Krakover, 2008, p. 129). Resource overlap and resource locking both matter for the collaboration value perceived by tourism firms (Zach and Racherla, 2011).

Strategic fit of coopetitors, such as similarities in mission, vision, strategy, mutual goals, and plans also influences coopetition success (Chin et al., 2008). Elements that encompass the compatibility of a firm's characteristics (Dorn et al., 2016), strategic goal congruence, and prospective strategies are seen among coopetition antecedents (Gnyawali and Park, 2009). Depending on the strategic goals pursued through coopetition fit, coopetition strategies may be translated into the search for: superior capabilities, distinct but complementary resource profiles, or similar capabilities (Bengtsson and Raza-Ullah, 2016). Evidence from the tourism industry shows that the more goals firms have in common, the more fluid, developed, and effective are the horizontal relationships exploited through coopetition networks (van der Zee and Vanneste, 2015). Moreover, organizational proximity, and its cultural dimension (Klimas, 
2016), is shown as significant for networking in tourism industry (Zach and Racherla, 2011). Hence, the extent to which tourism firms fit each other's strategic needs is often seen as an antecedent of tourism coopetition.

Participation in existing networks increases the likelihood of coopetition (Wang, 2008). A firm's position within networks has been demonstrated to influence the intensity of coopetitive actions, and structural autonomy increases the diversity of such actions (Gnyawali et al., 2006). The positive association between the number of relationships a tourism firm maintains and coopetition has been empirically substantiated (Della Corte and Aria, 2016). Additionally, social embeddedness plays a significant role in establishing collaboration with competitors in the tourism industry (Tortoriello et al., 2011). Social relationships, personal ties (Tsaur and Wang, 2011), a wide range of social bonds, and community feelings (von Friedrichs Grängsjö, 2003) influence the adoption of coopetition in tourism destinations. Existing networks are not limited to individual-level networks, as social proximity between organizations is one of the building blocks of positive network outcomes in tourism (Zach and Racherla, 2011).

Past experience is viewed as important for future collaboration with rivals (Gnyawali and Park, 2011). Experience impacts future partnering, including its preferred forms or partners (Dorn et al., 2016). Prior coopetition helps partners in developing a common knowledge base, which facilitates further collaborative endeavors (Bouncken et al., 2015). Both exposure to and prior experience of dealing with coopetition are seen as instrumental in developing and leveraging appropriate routines necessary to better handle coopetition relationships (Gnyawali et al., 2016). Interestingly, the development of routines, experience accumulation and cooperative orientation have been linked in prior research on coopetition (Bouncken and Frederich, 2015). Qualitative studies have found a learning curve effect in tourism coopetition: the more mature the approach is, the more collaboration with competitors takes place (Wang 
and Krakover, 2008). Both individual experience and the experience of participating in coopetitive networks are important behavioral variables in tourism coopetition studies (ChimMiki and Batista-Canino, 2017). Recent empirical findings on coopetition within and among tourist destinations have shown that past experience in working together influences both coordination of coopetitive actions and coopetitive behaviors in the future (Mariani, 2016). The awareness of benefits earned through prior collaboration has been recognized as playing a critical role in deciding on cooperating with business rivals (Zach and Racherla, 2011). Benefits that stem from short-term coopetitive actions can be sufficient to warrant taking the decision to extend, strengthen, and deepen coopetition in the long term (Kylänen and Mariani, 2012). Van der Zee and Vanneste (2015) have provided strong empirical evidence that increasing levels of cooperation between competitors stem from their prior cooperative experience. In particular, experience contributes to managers developing a mindset, through which they perceive and interpret their environment, better understand industry evolution, and make decisions (Schiavone and Simoni, 2011). Inversely, the lack of coopetition experience results in having a stereotypical viewpoint of competitors as rivals only, not as potential partners (Bagdoniene and Hopeniene, 2015).

Trust in partners is one of the most recurrently identified coopetition antecedents in the literature (Dorn et al., 2016). The development of mutual trust influences the successful adoption of a coopetition strategy in the long term (Chin et al., 2008), or can be a necessary precondition for the establishment of coopetition (Quintana-García and Benavides-Velasco, 2004). Trust-building activities are important to counterbalance the inherent risk of opportunistic behavior in coopetition (Dorn et al., 2016). Prior research conducted in the tourism industry points to the idea that trust is an important behavioral variable (Chim-Miki and Batista-Canino, 2017), both in pre-coopetition (Czernek and Czakon, 2016) and coopetition stages (Wang and Krakover, 2008). Trust is seen as a precursor of commitment to the 
relationship (Chim-Miki and Batista-Canino, 2017) thus preceding the coopetitive relationships' formation.

Partner's reputation refers to past behaviors and accomplishments of the prospective actor. It is an important factor in choosing a given coopetition partner, as it reduces perceived risks and uncertainty relative to collaboration with rivals (Bengtsson and Raza-Ullah, 2016). Recent empirical studies in tourism identify reputation as a necessary condition to engage in collective competition (Czakon and Czernek, 2016). Coopetitors' joint marketing efforts promote the destination (Bagdoniene and Hopeniene, 2015) and enhance their own reputations by using the partner's reputation, which in turn could trigger coopetition phenomena either with the same or new partners. Moreover, coopetition improves marketing and promotion of reputation at the tourist destination level (Beerli and Martin, 2004; Mariani, 2016; van der Zee and Vanneste, 2015; von Gränsjö, 2003; Wang and Krakover, 2008), and can be conducive to the development of the tourist destination image at multiple levels: municipal, regional, or national (Beerli and Martin, 2004; Stepchenkova and Li, 2014).

Cooperative orientation is useful for indicating that some firms have a greater proclivity towards partnering than others (Bouncken and Fredrich, 2016; Kylänen and Rusko, 2011). A constant search for new partners, nurturing existing ones, and the proneness to develop routines for managing relationships is typical in firms with greater cooperative orientation. Empirical evidence suggests that destinations represented by organizations to that show a willingness coopete can pool resources and capabilities to better promote themselves to the tourism market and external stakeholders (Kylänen, Mariani, 2012). Such a behavioral disposition towards coopeting has been detected in the banking sector franchise network (Czakon, 2009). Tourism studies reveal that a "cooperative mindset," as opposed to a "competitive mindset," characterizes individual businesses within a tourism destination (Wang and Krakover, 2008). Both the cooperative and competitive mindsets are closely connected with the perception of 
conflict between individual and common benefits (Wang, 2008). A cooperative mindset is observed when individual tourism firms participate in collective actions to achieve common goals, while a competitive mindset is characterized by the maximization of individual interests without collective action. This empirical observation corresponds to social psychology and behavioral economics research on individual behavior motives, which identifies self-regarding individuals as opposed to prosocial reciprocators (Bridoux and Stoelhorst, 2014). More recently, the coopetitive mindset refers to "people who have the cognitive frames and cognitive processes to understand and handle the paradox" (Gnyawali et al., 2016, p. 13). The diversity of mindsets among tourism managers seems in be important to understanding decisions whether or not to collaborate with competitors, and subsequently in understanding firm performance.

Current understanding of coopetition antecedents is fragmented (Bouncken et al., 2015). Available studies identify antecedents as a multi-level complex construct, yet without empirical measurement. Prior lists of coopetition antecedents are theory driven, mostly by resource-based view arguments. Also, managers are recognized as having incomplete knowledge and generating subjective interpretations and assumptions about competing organizations (Walley, 2007). This encourages a focus on managerial perceptions of coopetitive relationships (Della Corte and Aria, 2016), their propensities (Czakon, 2009), or orientations (Bouncken and Fredrich, 2012). Interestingly though, analysis at the individual manager level of analysis is vastly missing from extant literature.

Without formalizing the coopetition antecedents with a reliable and valid measure, it is difficult to conduct rigorous research to uncover the reasons why managers adopt coopetition, and help those who fail to appreciate the benefit of collaboration with competitors. In this study, we examine the convergent, discriminant, and nomological validity of the set of survey items developed to measure coopetition antecedents and identify the latent perceptions of individual managers regarding adopting coopetition. 


\section{Empirical research design}

The majority of research on coopetition has been based on conceptual or qualitative explorations, while quantitative studies represent less than $25 \%$ of available literature (Bouncken et al., 2015). Prior calls to measure managers' perceptions (Walley, 2007) still have not been answered (Chim-Miki and Batista-Canino, 2017; Della Corte and Aria, 2016; Van der Zee and Vaneste, 2015). Accordingly, we adopt a quantitative approach to identify coopetition antecedents with a focus on managerial perceptions. We investigate coopetition antecedents as latent constructs from a multi-level perspective on strategy research (Abell et al., 2008). Following the literature (Table 1), we note that coopetition antecedents refer to five different levels of analysis. However, two of them, i.e., network and inter-firm levels, only seem to be applicable in cross-industry investigations, as they do not differentiate potential coopetitors from one industry. Thus, we focus on the dyad, firm and individual levels.

\section{Questionnaire design}

We followed a conventional approach for management studies (Venkatraman and Grant, 1986), coopetition research (Walley, 2007) and for quantitative studies in tourism (Tsaur, Wang, 2011), that is a survey questionnaire with items to measure coopetition antecedents. A key argument in favor of the individual-level of analysis lies in the fundamental mandate of strategic management, which is to enable managers to gain and sustain competitive advantage (Abell et al., 2008).

The generation of scale items revolves around the construction of an inventory of items (Gerbing and Anderson, 1988) that could cover the theoretical antecedents identified in systematic literature reviews. Overall, 19 items corresponding to the different antecedents of coopetition were developed (Table 1). Consistent with the approaches suggested by Nunnally 
(1978) and Selltiz et al. (1976), i.e., that the subjects used for scale development should be those for whom the instrument is intended, we involved six managers and executives of six different tourism firms to select and purify a subset of items that could be meaningful in our research context (Churchill, 1979). We gathered comments on ambiguity, appropriateness, potential improvement in wording, and intelligibility of each item. This process led to several items being dropped, added, or reworded, ensuring the face validity (Gatignon et al., 2002), which is of particular importance for previously unexamined measurement items (Hardesty and Bearden, 2004). At the end of this process seven scale items remained (Table 3).

--- insert TABLE 3 about here ---

A five-point symmetric and equidistant Likert-type scale anchored on $1=$ "Strongly Disagree" and $5=$ "Strongly Agree" was applied to each scale item. This is useful for increasing the response rate, less confusing for interviewees (Dawes, 2008), and allows the approximation of interval-level measurement in structural modelling (Hair and Hult, 2016).

\section{Data gathering and sample}

We situated our study in the tourism industry as a suitable context for coopetition research (Chim-Miki and Batista-Canino, 2017). Observable specific technological and economic changes make the investigation of coopetition particularly relevant in the European context (Kylänen and Rusko, 2011). Thus, we purposefully chose to focus on firms that were members of 124 local tourism organizations (LTO), which were formal destination management organizations with well-developed coordination mechanisms covering the vast majority of industry players in Poland. 
In order to identify the target population, two databases were used: (a) the Polish Tourism Organization's database (available at: www.pot.gov.pl); (b) the database from the reputable online portal run by tourism organizations interested in intra-industry cooperation (www.forumLOT.pl). The integration of the two databases helped us to identify the population of tourism firms engaged in cooperation. Next, we excluded organizations that were not businesses, e.g., foundations, local/regional/national government units, research institutes, and associations, as well as inactive entities. As a result, we identified 1,647 tourism firms actively operating and associated with the LTOs. Given the population size $(1,647)$ and estimating the maximum measurement error at $50 \%$ with a significance level of $\alpha=0.03$, the targeted sample size was set at the minimal level of 367.

The data collection process was outsourced. The final sample covered 368 tourism firms picked up from the sampling frame defined and delivered by the research team. The sample was drawn by applying a simple random sampling technique, i.e., individual and unlimited random sampling using a random number generator. Twelve experienced interviewers used pen and paper interviews (PAPI) to gather the raw data. This technique ensures a better understanding of research aims and questions by respondents (Tsaur and Wang, 2011), regardless of their age and specific profession, especially when the phenomenon under consideration may be new to them (Kagerbauer et al., 2013). Moreover, face-to-face data-gathering methods increase response rates and alleviate issues with missing data. The data was collected between May and June 2016, directly from owners and top managers seen as the key informants in management research (Kumar et al., 1993). The final sample (Table 4) consists of 368 firms $^{1}$ represented predominantly by women (62.0\%), aged between 31 and $40(37.9 \%)$. The majority of firms (54.9\%) were family businesses operating in the most attractive tourist regions in Poland.

\footnotetext{
${ }^{1}$ The final sample of 368 meets requirements for the minimum sample size in research applying factor analysis, namely 5 observations for 1 item but no less than 200 (Gorsuch, 1983).
} 
--- insert TABLE 4 about here ---

Table 5 outlines the basic statistics of the measurement items.

$$
\text { --- insert TABLE } 5 \text { about here --- }
$$

We tested the raw data for common method bias (Podsakoff et al., 2003) using Harman's onefactor test (Kraus et al., 2012). The results showed no risk for common method bias (CMB), as $65.33 \%$ of the total variance was explained by the factor with the highest level of eigenvector, below the recommended threshold of $70 \%$ (Fuller et al., 2016).

\section{Data analysis}

This study uses structural equation modeling, appropriate for research targeting theory development through the creation and validation of measurement scales (Sutton et al., 2018), especially for examining complex (Hair and Hult, 2016) and relatively new managerial phenomena (Venkatraman and Grant, 1986). In particular, we assume that directly unmeasurable and unobservable coopetition antecedents may be reflected in specific, observable behaviors (e.g., formal and social relationships within networks), attitudes (e.g., manifested trust in competitors, the acknowledged reputation of the competitor, and cooperative orientation), perceived states (e.g., strategic fit in terms of resources), or conditions (e.g., mutually perceived and taken benefits) identified in prior studies (Tables 1 and 2). By triangulating the results of literature reviews with the insights from the pilot study, and after making efforts to ensure face validity, we administered a list of statements (Table 3 ) to our respondents. 
Following Gatignon et al. (2002), we assessed the reliability, convergent, discriminant, and nomological validity of coopetition antecedents (Danneels, 2016). We determined the Cronbach's coefficients alpha and average variance extracted (AVE), as a first-level diagnostic procedure for reliability. We ran factor analyses and then used structural regression (Byrne, 2010; Gefen et al., 2000). Exploratory factor analysis (EFA) was deployed in order to rigorously single out relevant coopetition antecedents (Govindarajan and Kopalle, 2006), and identify the structure of latent constructs perceived by mangers. Then, we conducted confirmatory factor analysis (CFA), which tested the proposed measurement model to validate that items were associated with specific factors identified using EFA and to establish discriminant validity. A reflective relationship between the construct and multiple measured items was assumed, as such directions of causality have usually been taken in research in management (Coltman et al., 2008), and in coopetition studies (Ghobadi and D'Ambra, 2012).

For empirical factor extraction in both EFA and CFA, we used a Promax with Kaiser normalization as a rotation method (Byrne, 2010; Field 2009) as the considered items may correlate (Table 6). The most commonly used principal component method is not recommended for analyses aimed at identifying items reflecting latent constructs (Morris et al., 2007). Therefore, we extracted factors using the generalized least squares method (GLS). This correlation-fitting factoring method is seen as suitable (Fabrigar et al., 1999) and provides efficient solutions (Jöreskog and Goldberger, 1972) in our research setting.

--- insert TABLE 6 about here ---

Initially we ran EFA without any imposed number of components. As a result, we received a two-factor solution using the eigenvalue greater than one with no risk of common method bias. However, recent literature often sees applying the Kaiser criterion (eigenvalue > 1) as 
controversial (Osborne and Costello, 2009), too strict (Lawless and Heymann, 2010), or misleading (Field, 2009). Therefore, we have imposed a three-factor solution based on literature reviews (Table 2). The Cattell's criterion considering the breaking point on the screen plot in a sample size larger than 200 (Field, 2009, p. 641) suggests that the three-factor solution is optimal. The three-factor solution yields a cumulative percentage of total variance explained at the level of $81.53 \%$, that is within the recommended range of $80 \%$ to $90 \%$ (Jolliffe, 2002, p. 112). Additionally, the screen plot starts flattening between the third and fourth factor. Common sense and interpretability criteria have been acknowledged as sound and sufficient (Lawless, Heymann, 2010).

To assess nomological validity, we examined the relationship of behavioral antecedents with superior value creation, measured at the dyadic and network coopetition levels. Nomological validity is the degree to which the focal construct is connected to other constructs in a way consistent with theoretical predictions (Danneels, 2016). Therefore, following the approach adopted by Gatignon et al. (2002), and Govindarajan and Kopalle (2006), nomological validity was tested measuring the effect of coopetition antecedents on a specific measure of value creation through coopetition. Ideally, measurement tests should be carried out on different samples and at two different points in time, but it is long recognized that strategy researchers seldom have such luxury (Venkatraman and Grant, 1986). We assessed nomological validity by conducting correlation and regression analyses on concurrent criteria, that is behavioral coopetition antecedents and tourism product complexity (TPC), as our data has been collected at one point of time. In particular, we expected that when: (1) the importance of strategic rationale as a reason to engage in coopetition increases; and (2) the importance of coopetitive mindset as a reason to engage in coopetition increases, firms should be able to create superior value reflected by increasing tourism product complexity (Kylänen and Mariani, 2012; Naipaul et al., 2009). Superior value creation in the highly interdependent, fragmented, and 
networked tourism setting (Chim-Miki and Batista-Canino, 2017) requires that firms reach out to many actors, including competitors, and build dense networks (Baggio, 2011). By doing so, tourism firms are able to offer complex, modular, and varied products to tourists (Naipaul et al., 2009), and can become more competitive because of higher coopetition degree (Della Corte and Aria, 2016). Accordingly, we asked managers to what extent coopetition was related to the offered tourism products complexity. The managers had to respond based on their experience in the previous three years.

We have controlled our results by the following variables: company size, and status of "family business." The findings were robust with respect to adding these control variables.

\section{Results}

To ensure that the basic requirements for factor analysis were met, we examined sampling adequacy and sphericity. The Bartlett's test provided significant $\mathrm{p}$ value, and the Kaiser-Meyer-Olkin measure exceeded 0.5 $(\mathrm{KMO}=0.905)$, which allows for conducting factor analysis. The results (Table 7) show that for the three-factor solution all components meet the requirements of internal consistency reliability as the Cronbach's $\alpha \in[0.7 ; 0.9]$.

--- insert TABLE 7 about here ---

The composite validity analysis shows that the levels of AVE for all components exceeds the required minimum level of 0.5 . However, the level of composite reliability $(\mathrm{CR})$ for the third component, i.e., rival's recognition, does not reach the minimum level of 0.7 in terms of Fornell and Larcker's (1981) requirements. Furthermore, one of the items (COOP_4: Participation in networks) was removed from further analyses as it does not meet the cut off for factor loadings, acknowledged at 0.5 (Hair et al., 2006). The exclusion of this item (COOP_4) makes the three- 
factor solution invalid, as the third factor would cover only one item (COOP_3: Partner's reputation) while in social sciences a multi-item approach is required (Churchill, 1979). As the loadings for all the remaining items met the even stricter threshold of 0.6 (Fornell and Larcker, 1981), we carried out further analyses with a two-factor solution including, two latent variables covering five items.

In order to test the factorial validity of the coopetition antecedents construct (Byrne, 2010), as well as to test and evaluate the mono-dimensionality of factors reflecting different groups of antecedents (Iacobucci, 2010; Morris et al., 2007) we run a CFA. The model consists of five observed and two latent variables (Figure 1).

\section{--- insert FIGURE 1 about here ---}

The CFA results indicate that all of the items are significant building blocks of the two-factor solution, which identifies coopetitive mindset and strategic rationale as coopetition antecedents. The model represents satisfactory goodness of fit, as all key indicators meet statistical requirements (Byrne, 2010; Iacobucci, 2010; McDonald, Ho, 2002; Singh, 2009;): CFI is 0.971, GFI is 0.990 , TFI is 0.928 , and RMSEA is 0.060 . Even though the Chi-square value of 9.273 $(\mathrm{df}=4 ; \mathrm{p}=0.05)$ and CMIN/Df $=2.318$ show the model as significant, we assess the model properly fits our data as CMIN is sensitive to the sample size (Vandenberg 2006, p. 197) and may give statistically significant chi-square values for non-small $(\mathrm{n}>250)$ samples (Marsh et al., 2004).

Even though the two-factor solution meets the Cronbach's alpha requirements (Table 8) there might be a risk that the real reliability of the measurement is underestimated due to the statistical shortcomings of the Cronbach's alpha approach (Tavakol and Dennick, 2011). Therefore, a detailed analysis of composite validity was run (Peterson and Kim, 2013). 
--- insert TABLE 8 about here ---

The analysis of composite validity aims at assessing convergent and discriminant validity in order to find out whether the items covered by a particular factor are interrelated (convergent validity), while they do not correlate significantly with items covered by another factor(s) (discriminant validity) (Campbell and Fiske, 1959). Following Fornell and Larcker (1981) and Peterson and Kim (2013), our tests showed no risk for composite invalidity. Convergent validity was supported, as composite reliabilities exceeded a threshold of 0.7 , and average variance extracted exceeded the threshold of 0.5. Also, convergent validity was supported as both AVEs exceeded the squared factor correlation. Finally, we examined nomological validity in two ways, using correlation (Govindarajan and Kopalle, 2006) and regression analyses (Danneels, 2016). In both cases, the scales for constructs were computed as the mean of the items (Danneels, 2016). First, the correlation analysis was run. Its results indicated positive and significant links between strategic rationale, coopetitive mindset, and tourism product complexity (the range from 0.369 to 0.463 ; all were significant at $\mathrm{p}<0.01$ ). Second, multiple regression models were used to assess the effect of coopetition antecedents on tourism product complexity (Table 9). Both coopetitive mindset and strategic rationale exerted a significantly positive effect (respectively at $\mathrm{p}<0.001$, and $\mathrm{p}<0.01$ ) on tourism product complexity. The findings are in line with theoretical expectations as the behavioral antecedents reflect positive, significant, and moderate explanatory power (Table 9). Considering the results of both analyses the scale is valid from the nomological perspective.

--- insert TABLE 9 about here --- 
Our controls (company size and the dummy family firm) did not affect significantly our dependent variable. The results show that the model has a good overall fit. Given the effects of considered antecedents may not be totally independent from one another, the models including interaction of antecedents were included in the regression analysis (Gatignon et al., 2002).

\section{Discussion and conclusions}

It is important to understand why some firms adopt coopetition while others facing the same strategic challenges do not. Our analyses contribute to elucidate why coopetition appears to various degrees and takes various forms in tourism destinations (Tuohino and Konu, 2014). In particular, using prior theoretical considerations and fragmented findings, we integrate previous literature on coopetition antecedents (Tables 1-3), and empirically examine how those behavioral antecedents of coopetition come together in tourism industry. The lack of valid measures is a major impediment to progress in management research (Danneels, 2016) and could undermine the development of an integrated body of knowledge (Sutton et al., 2018) on coopetition antecedents. Developing ways to measure antecedents requires their specification and delineation. We take a behavioral stance to capture the managers' perceptions about the antecedents of coopetition adoption. We have quantified individual manager's perceptions in order to complement the traditional view of managers as rational utility maximizing individuals, with a behavioral approach incorporating their individual perceptions (Walley, 2007).

This study contributes to coopetition research by providing and formally testing scales to measure behavioral antecedents of coopetition. It may be adopted across a wide range of industries and geographical contexts in order to accelerate the creation and integration of sound, generalizable knowledge about coopetition. This step is even more relevant given that coopetition is commonly acknowledged as an industry-specific (Czakon et al., 2014), culturally dependent (Klimas, 2016), and country-sensitive (Luo, 2005, 2007) phenomenon. 
Our results show coopetition as an "explicit, rational strategic choice (...) being a result of conscious, strategic planning” (Kylänen, Rusko, 2011, p. 194). This strengthens the argument that coopetition is more than a phenomenon (Raza-Ullah et al., 2014) or a relationship (Bengtsson and Kock, 2000), but rather a strategy adopted in order to achieve clear-cut strategic objectives (Bouncken et al., 2015). We find that strategic rationale and coopetitive mindset, which incorporate respectively the rational and behavioral approaches to strategy (Levinthal, 2011), to be both conceptually and empirically distinct behavioral coopetition antecedents.

Behavioral economists suggest that motivational heterogeneity has implications for stakeholder sorting, that is actively selecting and self-selecting to associate with certain firms (Bridoux, Stoelhorst, 2014). Hence, firms with competitive mindsets are suggested to associate with like-minded, individual, benefit-oriented actors. Similarly, firms with collaborative mindset are expected to associate with firms seeking common goals through collective action (Wang, 2008). However, a coopetitive mindset implies the ability to work with both types of actors, whether they are competitively or collaboratively oriented. Consequently, the pool of opportunities attainable by managers with a coopetitive mindset is broader than either those who are competitively oriented, or those who are collaboratively oriented. Our study suggests that as the strength of managers' coopetitive mindset increases, the more likely complex products and services are offered in collaboration with competitors. Managers are more able to seize superior value creation opportunities when they display a coopetitive mindset.

The coopetitive mindset construct receives a new operationalization based on our reflective analysis. We find evidence for prior claims that trust (Czernek and Czakon, 2016; Morris et al., 2007), experience in coopetition (Czakon and Czernek, 2016; Della Corte and Aria, 2016; Kylänen and Rusko, 2011), and cooperative orientation (Bouncken and Fredrich, 2016; Wang and Krakover, 2008;) are each, separately, relevant antecedents of coopetition. However, our study also shows that these three items converge to form one single, directly 
unobservable construct - the coopetitive mindset. We empirically ground prior theoretical suggestions of coopetitive mindset complexity (Gnyawali and Park, 2011), which is built on common experience, long-term commitment, mutual understanding, and trust (Seran et al., 2016). Experience in coopetition offers the benefits of experiential learning (Baumard, 2010). Beyond knowledge of a partner firm's behaviors, experience helps develop routines for effective collaboration with competitors (Gnyawali et al. 2016). While empirical research suggests that experience is relevant for coordination purposes in coopetitive relationships (Mariani, 2016), our evidence indicates that it also plays an important role in engaging in coopetition (Zach and Racherla, 2011).

Cognitive antecedents have so far been absent from large sample coopetition studies. We provide empirical grounds for the behavioral approach to strategy in that the attention of managers is focused on opportunities to collaborate with competitors to different degrees (Ocasio, 1997). In order to embrace coopetition, it is necessary to incorporate collaboration with competitors as a strategic option in the plethora of choices considered by managers. We find evidence that managers vary in their disposition to coopete. Our scale helps further develop the concepts of: propensity to coopete (Czakon, 2009), proclivity to collaborate (Bouncken and Fredrich, 2016), cooperative orientation (Wang and Krakover, 2008), and collaborative culture (Kylänen and Rusko, 2011). Orientation to cooperation is an individual manager's characteristic, but it converges to the same coopetition mindset construct as experience. This suggests that the preference for collaboration is not a stable personality trait but can be learned through experience.

By highlighting that strategic rationale is a relevant construct, we corroborate prior qualitative findings that relate coopetition to a strategic way of thinking (Wang, 2008). We find strong evidence that perceived benefits (Ritala, 2012) and strategic fit (Luo, 2005), previously indicated in the literature, converge into one construct of rational strategic decision-making. 
Our respondents make the connection between the benefits they strive for, and the perception of a competitor that makes a strategic fit. Even if potential benefits available through coopetition, such as compatible resource endowment or an individual need for resource acquisition (Dorn, et al. 2016) are perceived by the manager, in addition, a fitting competitor is needed. Therefore firm-level and dyad-level antecedents (Bengtsson, Raza-Ullah, 2016) can form one level of analysis from the perspective of an individual manager. Thus, we find evidence that strategic rationale for coopetition is complex, with potentially various degrees of manifestation (Wang and Krakover, 2008), depending on the benefits sought and available coopetitors' perception.

\section{Limitations and implications for research}

Our study has been conducted in line with several methodological choices that also pose some limitations. The focus on managerial perceptions unveils one subset of coopetition antecedents. We have developed a psychometrically distinct and reliable scale for behavioral antecedents of coopetition. Other measures can be developed to assess further aspects of coopetition adoption, connected for example with exogenous factors such as: structural contingencies of industry networks, the dynamics of a firm's environment, or disruptions. The approach exemplified in our study could provide a template for testing and validating these new measures.

The population we have studied is composed of managers who are engaged in collaborative activities and aware of the interdependencies that constrain action in the tourism industry. Our population choice may have overemphasized coopetition at the expense of individual agency. It would be fruitful for future studies to examine other types of informants, and the organizational processes that contribute to the adoption of a coopetitive mindset among the top management team. Our measure can be useful in studying the distribution of a 
coopetitive mindset and strategic rationale across the organizational hierarchy (Gavetti, 2005), in order to examine the distribution of perceptions about coopetition. This may open ways for a better understanding of coopetition as a dominant logic (Bettis and Prahalad, 1995).

Also, our behavioral coopetition antecedents scale may be useful in identifying the individual-level heterogeneity for coopetition adoption and help understand how these behavioral antecedents contribute to the heterogeneity of capabilities at firm level. Whether or not firms with a strong strategic rationale and coopetitive mindset actually exhibit coopetitive behaviors and successfully embrace coopetition may be contingent on various organizationallevel factors. For instance, extending a coopetitive mindset to the firm level (Abell et al., 2008) in order to mobilize macro-level phenomena, such as culture, may offer insights on antecedents that are so far seldom explored in coopetition studies (Klimas, 2016). Our measure may also be useful in examining the relationship between coopetitive capabilities and behavioral antecedents, and in particular the performance implications of these behavioral antecedents.

The choice of the tourism industry, as a strongly connected and interdependent service sector may overstate industry-level antecedents, at the expense of firm-level ones. Another extension of our study can therefore reach out to other industries and other settings. Coopetition is an industry-specific phenomenon; therefore, further research should seek external validation of scales across industries. In particular, developing behavioral antecedent measures appropriate for manufacturing firms and for innovative activities may contribute to further accumulate knowledge on what brings competitors to work together. Combining the industrylevel findings with firm level findings might allow for the testing of the theoretical model proposed by Gnyawali and Park (2009) for SMEs.

We argue that a clear understanding of the antecedents of coopetition, while important for establishing a coopetition theory and harnessing the managerial potential of this strategy, is far from complete. Therefore, we believe that longitudinal and experimental studies may offer 
additional insights into the process of coopetition adoption. When relevant antecedents are gathered, it takes time and a pattern of action to establish coopetitive relationships. Also, an indepth study considering time may offer valuable insights into the coopetition antecedents and formation process.

\section{Acknowledgement}

We wish to thank the two anonymous Long Range Planning reviewers for their challenging, valuable, and insightful comments, which have greatly helped us to improve our study.

\section{References}

Abell, P., Felin, T., Foss, N., 2008. Building micro- foundations for the routines, capabilities, and performance links. Managerial and Decision Economics, 29 (6), 489-502.

Bagdoniene, L., Hopeniene, R., 2015. Coopetition usefulness: what do the agents of Lithuanian travel trade market think? Procedia-Social and Behavioral Sciences, 213, 824-829.

Baggio, R., 2011. Collaboration and cooperation in a tourism destination: a network science approach. Current Issues in Tourism, 14 (2), 183-189.

Barretta, A., 2008,. The functioning of co-opetition in the health-care sector: An explorative analysis. Scandinavian Journal of Management, 24(3), 209-220.

Baumard, P., 2010. Learning in coopetitive environments, in: Yami, S., Castaldo, S., Dagnino, G, Le Roy, F. (Eds.), Coopetition: Winning Strategies for the 21st Century. Routledge, London, 74-100.

Beerli, A., Martin, J.D., 2004. Factors influencing destination image. Annals of Tourism Research, 31 (3), 657-681.

Belleflamme, P., Neysen, N., 2006. Coopetition in Information: The Ruraltrip.com Case. ECON Discussion Papers; 2006/05.

Bengtsson, M., Kock, S., 2000. "Coopetition" in business networks - to cooperate and compete simultaneously. Industrial Marketing Management, 29 (5), 411-426.

Bengtsson, M., Kock, S., 2014. Coopetition-quo vadis? Past accomplishments and future challenges. Industrial Marketing Management, 43 (2), 180-188.

Bengtsson, M., Raza-Ullah, T., 2016. A systematic review of research on coopetition: Toward a multilevel understanding. Industrial Marketing Management, 57, 23-29.

Bengtsson, M., Raza-Ullah, T., Vanyushyn, V., 2016. The coopetition paradox and tension: The moderating role of coopetition capability. Industrial Marketing Management, 53, 19-30.

Bettis, R.A., Prahalad, C.K., 1995. The dominant logic: retrospective and extension. Strategic Management Journal, 16 (1), 5-14. 
Björk, P., Virtanen, H., 2005. What tourism project managers need to know about co- operation facilitators. Scandinavian Journal of Hospitality and Tourism, 5 (3), 212-230.

Bouncken, R.B., Fredrich, V., 2012. Coopetition: performance implications and management antecedents. International Journal of Innovation Management, 16 (5), 1250028.

Bouncken, R.B., Fredrich, V., 2016. Learning in coopetition: alliance orientation, network size, and firm types. Journal of Business Research, 69 (5), 1753-1758.

Bouncken, R.B., Gast, J., Kraus, S., Bogers, M., 2015. Coopetition: a systematic review, synthesis, and future research directions. Review of Managerial Science, 9 (3), 577-601.

Brandenburger, A.M., Nalebuff, B.J., 1996. Co-opetition: A Revolutionary Mindset that Combines Competition and Cooperation in the Marketplace. Harvard Business School Press, Boston.

Bridoux, F., Stoelhorst, J.W., 2014. Microfoundations for stakeholder theory: managing stakeholders with heterogeneous motives. Strategic Management Journal, 35 (1), 107125 .

Byrne, B.M. (2010). Structural Equation Modeling with AMOS: Basic Concepts, Applications, and Programming, second ed. Routledge: Taylor and Francis Group.

Campbell, D.T., Fiske, D.W., 1959. Convergent and discriminant validation by the multitraitmultimethod matrix. Psychological bulletin, 56 (2), 81-105.

Chiambaretto, P., Massé, D., Mirc, N., 2018. “All for one and one for all?” Knowledge broker roles in managing tensions of internal coopetition: the Ubisoft case. Research Policy. https://doi.org/10.1016/j.respol.2018.10.009.

Cheng, J. H., Yeh, C. H., Tu, C. W., 2008, Trust and knowledge sharing in green supply chains. Supply Chain Management: An International Journal, 13(4), 283-295.

Chim-Miki, A.F., Batista-Canino, R.M., 2017. The coopetition perspective applied to tourism destinations: a literature review. Anatolia, 28 (3), 381-393.

Chin, K.S., Chan, B.L., Lam, P.K., 2008. Identifying and prioritizing critical success factors for coopetition strategy. Industrial Management \& Data Systems, 108 (4), 437-454.

Churchill Jr., G.A., 1979. A paradigm for developing better measures of marketing constructs. Journal of marketing research, 16, 64-73.

Coltman, T., Devinney, T.M., Midgley, D.F., Venaik, S., 2008. Formative versus reflective measurement models: two applications of formative measurement. Journal of Business Research, 61 (12), 1250-1262.

Czakon, W., 2009. Power asymmetries, flexibility and the propensity to coopete: an empirical investigation of SMEs' relationships with franchisors. International Journal of Entrepreneurship and Small Business, 8 (1), 44-60.

Czakon, W., Mucha-Kuś, K., Rogalski, M., 2014. Coopetition research landscape-A systematic literature review 1997-2010. Journal of Economics and Management, 17, $122-150$. 
Czakon, W., Czernek, K., 2016. The role of trust-building mechanisms in entering into network coopetition: The case of tourism networks in Poland. Industrial Marketing Management, $57,64-74$.

Czernek, K., Czakon, W., 2016. Trust-building processes in tourist coopetition: The case of a Polish region. Tourism Management, 52, 380-394.

Damayanti, M., Scott, N., Ruhanen, L., 2017. Coopetitive behaviours in an informal tourism economy. Annals of Tourism Research, 65, 25-35

Danneels, E., 2016. Survey measures of first- and second- order competences. Strategic Management Journal, 37 (10), 2174-2188.

Dawes, J., 2008. Do data characteristics change according to the number of scale points used? An experiment using 5-point, 7-point and 10-point scales. International journal of market research, 50 (1), 61-104.

Della Corte, V., Aria, M., 2016. Coopetition and sustainable competitive advantage. The case of tourist destinations. Tourism Management, 54, 524-540.

Dorn, S., Schweiger, B., Albers, S., 2016. Levels, phases and themes of coopetition: A systematic literature review and research agenda. European Management Journal, 34 (5), $484-500$.

Eriksson, P. E., 2008. Procurement effects on coopetition in client-contractor relationships. Journal of Construction Engineering and Management, 134(2), 103-111.

Fabrigar, L.R., Wegener, D.T., MacCallum, R.C., Strahan, E.J., 1999. Evaluating the use of exploratory factor analysis in psychological research. Psychological methods, 4 (3), 272 299.

Fernandez, A.S., Le Roy, F., Chiambaretto, P., 2017. Implementing the right project structure to achieve coopetitive innovation projects. Long Range Planning, 51 (2), 384-405.

Field, A., 2009. Discovering Statistics Using SPSS, third ed. Sage Publications.

Fornell, C., Larcker, D.F., 1981. Structural equation models with unobservable variables and measurement error: algebra and statistics. Journal of marketing research, 18, 382-388.

Frankenberger, K., Sauer, R., 2018. Cognitive antecedents of business models: exploring the link between attention and business model design over time. Long Range Planning, in press, https://doi.org/10.1016/j.lrp.2018.05.001.

Fuller, C.M., Simmering, M.J., Atinc, G., Atinc, Y., Babin, B.J., 2016. Common methods variance detection in business research, Journal of Business Research, 69 (8), 3192-3198.

Gaim, M., Wåhlin, N., 2016. In search of a creative space: a conceptual framework of synthesizing paradoxical tensions. Scandinavian Journal of Management, 32 (1), 33-44.

Gatignon, H., Tushman, M.L., Smith, W., Anderson, P., 2002. A structural approach to assessing innovation: construct development of innovation locus, type, and characteristics. Management Science, 48 (9), 1103-1122.

Gavetti, G., 2005. Cognition and hierarchy: rethinking the microfoundations of capabilities' development. Organization Science, 16 (6), 599-617.

Gavetti, G., 2012. Toward a behavioral theory of strategy. Organization Science, 23 (1), 267285. 
Gefen, D., Straub, D., Boudreau, M.C., 2000. Structural equation modeling and regression: Guidelines for research practice. Communications of the Association for Information systems, 4 (1), 7, https://doi.org/10.17705/1CAIS.00407.

Gerbing, D.W., Anderson, J.C., 1988. "An updated paradigm for scale development incorporating unidimensionality and its assessment", Journal of Marketing Research, 25, (May), 186-192.

Ghobadi, S., D'Ambra, J., 2012. Coopetitive relationships in cross-functional software development teams: How to model and measure? Journal of Systems and Software, 85 (5), 1096-1104.

Govindarajan, V., Kopalle, P.K., 2006. Disruptiveness of innovations: measurement and an assessment of reliability and validity. Strategic Management Journal, 27 (2), 189-199.

Gnyawali, D.R., He, J., Madhavan, R., 2006. Impact of co-opetition on firm competitive behavior: An empirical examination. Journal of Management, 32 (4), 507-530.

Gnyawali, D.R., Madhavan, R., He, J., Bengtsson, M., 2016. The competition-cooperation paradox in inter-firm relationships: a conceptual framework. Industrial Marketing Management, 53, 7-18.

Gnyawali, D.R., Park, B.J. 2009. Co- opetition and technological innovation in small and medium- sized enterprises: a multilevel conceptual model. Journal of Small Business Management, 47 (3), 308-330.

Gnyawali, D.R., Park, B.J., 2011. Co-opetition between giants: collaboration with competitors for technological innovation. Research Policy, 40 (5), 650-663.

Gorsuch, R., 1983. Factor Analysis. Lawrence Erlbaum Associates, London

Hair, J.F., Black, W.C., Babin, B.J., Anderson, R.E., Tatham, R.L., 2006. Multivariate data analysis, sixth ed.

Hair Jr, J.F., Hult, G.T.M., 2016. A primer on partial least squares structural equation modeling (PLS-SEM). Sage Publications.

Hardesty, D.M., Bearden, W.O., 2004. The use of expert judges in scale development: Implications for improving face validity of measures of unobservable constructs. Journal of Business Research, 57 (2), 98-107.

Iacobucci, D., 2010. Structural equations modeling: fit indices, sample size, and advanced topics. Journal of Consumer Psychology, 20 (1), 90-98.

Jolliffe, I., 2002. Principal component analysis, second ed. John Wiley \& Sons, Ltd.

Jöreskog, K.G., Goldberger, A.S., 1972. Factor analysis by generalized least squares. Psychometrika, 37 (3), 243-260.

Kagerbauer, M., Manz, W., Zumkeller, D., 2013. Analysis of PAPI, CATI, and CAWI methods for a multiday household travel survey, in: Zmud, J., Lee-Gosselin, M., Carrasco, J. M., Munizaga, M.A. (Eds.), Transport Survey Methods: Best Practice for Decision Making, Emerald Group Publishing. https://doi.org/10.1108/9781781902882-015.

Klimas, P., 2016. Organizational culture and coopetition: An exploratory study of the features, models and role in the Polish aviation industry. Industrial Marketing Management, 53, 91-102. 
Kotzab, H., Teller, C. , 2003. Value-adding partnerships and co-opetition models in the grocery industry. International Journal of Physical Distribution \& Logistics Management, 33(3), 268-281.

Kraus, S., Rigtering, J.C., Hughes, M., Hosman, V., 2012. Entrepreneurial orientation and the business performance of SMEs: a quantitative study from the Netherlands. Review of Managerial Science, 6 (2), 161-182.

Kumar, N., Stern, L.W., Anderson, J.C., 1993. Conducting interorganizational research using key informants. Academy of Management Journal, 36 (6), 1633-1651.

Kylänen, M., Mariani, M.M., 2012. Unpacking the temporal dimension of coopetition in tourism destinations: evidence from Finnish and Italian theme parks. Anatolia, 23 (1), $61-74$.

Kylänen, M., Rusko, R., 2011. Unintentional coopetition in the service industries: The case of Pyhä-Luosto tourism destination in the Finnish Lapland. European Management Journal, 29 (3), 193-205.

Laamanen, T., Maula, M., Kajanto, M., Kunnas, P., 2017. The role of cognitive load in effective strategic issue management. Long Range Planning, in press, http://doi.org/10.1016/j.lrp.2017.03.001.

Lai, K. K., Su, F. P., Weng, C. S., Chen, C. L., 2007. Co-opetition strategy from the patent analysis perspective: the case of the stent market. International Journal of Innovation and Technology Management, 4(02), 137-153.Lawless, H.T., Heymann, H. (2010). Sensory evaluation of food: principles and practices. Springer Science \& Business Media.

Le Roy, F., Czakon, W., 2016. Managing coopetition: the missing link between strategy and performance. Industrial Marketing Management, 53, 3-6.

Le Roy, F., Fernandez, A.S., Chiambaretto, P., 2018. From strategizing coopetition to managing coopetition, in: Fernandez, A.S., Chiambaretto, P., Le Roy, F., Czakon, W. (Eds.), Routledge Companion to Coopetition Strategies, Routledge, London.

Levinthal, D.A., 2011. A behavioral approach to strategy-what's the alternative? Strategic Management Journal, 32 (13), 1517-1523.

Lundgren-Henriksson, E.L., Kock, S., 2016. A sensemaking perspective on coopetition. Industrial Marketing Management, 57, 97-108.

Luo, X., Slotegraaf, R.J., Pan, X., 2006. Cross-functional "coopetition": The simultaneous role of cooperation and competition within firms. Journal of Marketing, 70 (2), 67-80.

Luo, Y., 2005. Toward coopetition within a multinational enterprise: A perspective from foreign subsidiaries. Journal of World Business, 40 (1), 71-90.

Luo, Y., 2007. A coopetition perspective of global competition. Journal of world business, 42 (2), 129-144.

Lydeka, Z., Adomavičius, B., 2007. Cooperation among the competitors in international cargo transportation sector: key factors to success. Engineering Economics, 51(1), 80-90.

Mariani, M.M., 2007. Coopetition as an emergent strategy: empirical evidence from an Italian consortium of opera houses. International Studies of Management \& Organization, 37 (2), 97-126. 
Mariani, M.M., 2016. Coordination in inter-network co-opetitition: evidence from the tourism sector. Industrial Marketing Management, 53, 103-123.

Marsh H.W., Hau K-T., Wen Z., 2004. In search of golden rules: comment on hypothesistesting approaches to setting cutoff values for fit indexes and dangers in overgeneralizing $\mathrm{Hu}$ and Bentler's (1999) findings. Structural Equation Modeling: A Multidisciplinary Journal, 11 (3), 320-341.

McDonald, R.P., Ho, M.H.R., 2002. Principles and practice in reporting structural equation analyses. Psychological methods, 7 (1), 64-82.

Morris, M.H., Koçak, A., Özer, A., 2007. Coopetition as a small business strategy: implications for performance. Journal of Small Business Strategy, 18 (1), 35-55.

Naipaul, S., Wang, Y., Okumus, F., 2009. Regional destination marketing: a collaborative approach. Journal of Travel \& Tourism Marketing, 26 (5-6), 462-481.

Narayanan, V.K., Zane, L.J., Kemmerer, B., 2011. The cognitive perspective in strategy: an integrative review. Journal of Management, 37 (1), 305-351.

Nunnally, J.C., 1978. Psychometric Theory, second ed. McGraw-Hill Book Company, New York, NY.

Ocasio, W., 1997. Towards an attention- based view of the firm. Strategic Management Journal, 18 (S1), 187-206.

Osarenkhoe, A., 2010. A study of inter-firm dynamics between competition and co-operation a coopetition strategy. Database Marketing \& Customer Strategy Management, 17(3/4), 201-221.

Osborne, J.W., Costello, A.B., 2009. Best practices in exploratory factor analysis: Four recommendations for getting the most from your analysis. Pan-Pacific Management Review, 12 (2), 131-146.

Padula, G., Dagnino, G. B., 2007. Untangling the rise of coopetition: the intrusion of competition in a cooperative game structure. International Studies of Management \& Organization, 37(2), 32-52.

Peterson, R.A., Kim, Y., 2013. On the relationship between coefficient alpha and composite reliability. Journal of Applied Psychology, 98 (1), 194-198.

Podsakoff, P.M., MacKenzie, S.B., Lee, J.Y., Podsakoff, N.P., 2003. Common method biases in behavioral research: a critical review of the literature and recommended remedies. Journal of Applied Psychology, 88 (5), 879-903.

Quintana-García, C., Benavides-Velasco, C.A., 2004. Cooperation, competition, and innovative capability: a panel data of European dedicated biotechnology firms. Technovation, 24 (12), 927-938.

Raza-Ullah, T., Bengtsson, M., Kock, S., 2014. The coopetition paradox and tension in coopetition at multiple levels. Industrial Marketing Management, 43 (2), 189-198.

Ritala P. (2012). Coopetition strategy-when is it successful? Empirical evidence on innovation and market performance. British Journal of Management, 23 (3), 307-324.

Ritala, P., Hurmelinna-Laukkanen, P., 2009. What's in it for me? Creating and appropriating value in innovation-related coopetition. Technovation, 29 (12), 819-828. 
Ritala, P., Tidström, A., 2014. Untangling the value-creation and value-appropriation elements of coopetition strategy: A longitudinal analysis on the firm and relational levels. Scandinavian Journal of Management, 30 (4), 498-515.

Schiavone, F., Simoni, M., 2011. An experience-based view of co-opetition in R\&D networks. European Journal of Innovation Management, 14 (2), 136-154.

Selltiz, C., Wrightsman, L.S., Cook, S.W., 1976, Research Methods in Social Relations, third ed. Holt, Rinehart, and Winston, New York, NY.

Seran, T., Pellegrin-Boucher, E., Gurau, C., 2016. The management of coopetitive tensions within multi-unit organizations. Industrial Marketing Management, 53, 31-41.

Singh, R., 2009). Does my structural model represent the real phenomenon? A review of the appropriate use of structural equation modelling (SEM) model fit indices. The Marketing Review, 9 (3), 199-212.

Stepchenkova, S., Li, X., 2014. Destination image: do top-of-mind associations say it all? Annals of Tourism Research, 45, 46-62.

Sutton, C., Veliyath, R., Pieper, T.M., Hair Jr., J.F., Caylor, M., 2018. Secondary agency conflicts: a synthesis and proposed measurement model. Long Range Planning, 51 (5), 720-735.

Tavakol, M., Dennick, R., 2011. Making sense of Cronbach's alpha. International Journal of Medical Education, 2, 53-55.

Tortoriello, M., Perrone, V., McEvily, B., 2011. Cooperation among competitors as statusseeking behavior: network ties and status differentiation. European Management Journal, 29 (5), 335-346.

Tuohino, A., Konu, H., 2014. Local stakeholders' views about destination management: who are leading tourism development? Tourism Review, 69 (3), 202-215.

Tsaur, S.H., Wang, C.H., 2011. Personal ties, reciprocity, competitive intensity, and performance of the strategic alliances in Taiwan's travel industry. The Service Industries Journal, 31 (6), 911-928.

van der Zee, E., Vanneste, D., 2015. Tourism networks unravelled; a review of the literature on networks in tourism management studies. Tourism Management Perspectives, 15, 46-56.

Vandenberg, R.J., 2006. Introduction: statistical and methodological myths and urban legends: where, pray tell, did they get this idea? Organizational Research Methods, 9 (2), 194201.

Venkatraman, N., Grant, J.H. 1986. Construct measurement in organizational strategy research: A critique and proposal. Academy of Management Review, 11 (1), 71-87.

von Friedrichs Grängsjö, Y., 2003. Destination networking: co-opetition in peripheral surroundings. International Journal of Physical Distribution \& Logistics Management, 33 (5), 427-448.

von Friedrichs Grängsjö, Y., Gummesson, E., 2006). Hotel networks and social capital in destination marketing. International Journal of Service Industry Management, 17(1), 5875 .

Walley, K., 2007. Coopetition: an introduction to the subject and an agenda for research. International Studies of Management \& Organization, 37 (2), 11-31. 
Wang, Y., 2008. Collaborative destination marketing understanding the dynamic process. Journal of Travel Research, 47 (2), 151-166.

Wang, Y., Krakover, S., 2008. Destination marketing: competition, cooperation or coopetition? International Journal of Contemporary Hospitality Management, 20 (2), 126-141.

Werner, K., Dickson, G., Hyde, K.F. (2015). Coopetition and knowledge transfer dynamics: New Zealand's regional tourism organizations and the 2011 Rugby World Cup. Event Management, 19(3), 365-380.

Zach, F., Racherla, P., 2011. Assessing the value of collaborations in tourism networks: a case study of Elkhart County, Indiana. Journal of Travel \& Tourism Marketing, 28 (1), 97110. 
Table 1. Coopetition antecedents identified in systematic literature reviews.

\begin{tabular}{|c|c|c|c|c|}
\hline $\begin{array}{l}\text { Level of } \\
\text { analysis }\end{array}$ & Dorn et al. (2016) & $\begin{array}{l}\text { Bengtsson and Raza- } \\
\text { Ullah (2016) }\end{array}$ & $\begin{array}{l}\text { Czakon et al. } \\
(2014)\end{array}$ & $\begin{array}{l}\text { Chim-Miki and } \\
\text { Batista-Canino (2017) }\end{array}$ \\
\hline Network & $\begin{array}{l}\text { Firm's position } \\
\text { (centrality) within a } \\
\text { network } \\
\text { Compatibility of } \\
\text { characteristics of firms } \\
\text { within a network }\end{array}$ & $\begin{array}{l}\text { Structural } \\
\text { interdependency } \\
\text { Social exchange }\end{array}$ & $\begin{array}{l}\text { Social networks } \\
\text { Mimetism }\end{array}$ & $\begin{array}{l}\text { Strategic response to } \\
\text { challenges } \\
\text { Common goal of } \\
\text { developing a } \\
\text { destination } \\
\text { Leadership }\end{array}$ \\
\hline $\begin{array}{l}\text { Inter-firm } \\
\text { level }\end{array}$ & $\begin{array}{l}\text { Market conditions } \\
\text { Specific industry } \\
\text { settings } \\
\text { High degree of change } \\
\text { and competition } \\
\text { Regulatory bodies } \\
\text { enforcing/prohibiting } \\
\text { coopetition }\end{array}$ & $\begin{array}{l}\text { Industrial characteristics } \\
\text { Technological demands } \\
\text { (convergence, life-cycle, } \\
\text { uncertainty, complexity) } \\
\text { Influential stakeholders }\end{array}$ & $\begin{array}{l}\text { Deregulation } \\
\text { Globalization }\end{array}$ & $\begin{array}{l}\text { Governance and } \\
\text { industrial } \\
\text { competitiveness } \\
\text { Stakeholders' pressure } \\
\text { Institutional } \\
\text { environment } \\
\text { Competition }\end{array}$ \\
\hline Dyad level & $\begin{array}{l}\text { Compatible resource } \\
\text { endowment } \\
\text { Presence of trust } \\
\text { Extant ties of potential } \\
\text { partner firms }\end{array}$ & $\begin{array}{l}\text { Partner characteristics } \\
\text { (resources } \\
\text { complementarity, } \\
\text { knowledge asymmetry, } \\
\text { goal congruity) } \\
\text { Relationship } \\
\text { characteristics } \\
\text { (flexibility, trust) }\end{array}$ & $\begin{array}{l}\text { Resource } \\
\text { interdependency }\end{array}$ & $\begin{array}{l}\text { Commitment } \\
\text { Trust }\end{array}$ \\
\hline Firm level & $\begin{array}{l}\text { Need for knowledge } \\
\text { and resource } \\
\text { acquisition } \\
\text { Self-perception of the } \\
\text { firm (e.g., } \\
\text { vulnerability, position, } \\
\text { strategy) }\end{array}$ & $\begin{array}{l}\text { Goals, capabilities } \\
\text { Prospective strategies } \\
\text { Perceived vulnerability } \\
\text { Past experience }\end{array}$ & - & $\begin{array}{l}\text { Community feelings } \\
\text { Social relationship } \\
\text { Motives and values of } \\
\text { individuals }\end{array}$ \\
\hline Individual & $\begin{array}{l}\text { Interdependence of } \\
\text { units and simultaneous } \\
\text { competition for } \\
\text { parents' resources }\end{array}$ & - & $\begin{array}{l}\text { Managerial } \\
\text { propensity }\end{array}$ & - \\
\hline
\end{tabular}


Table 2. Antecedents of coopetition in tourism context.

\begin{tabular}{|c|c|c|c|}
\hline Antecedents & General references* & Empirical investigation in tourism & Dimensions \\
\hline $\begin{array}{l}\text { Cooperative } \\
\text { orientation }\end{array}$ & $\begin{array}{l}\text { Bouncken and Fredrich (2012); } \\
\text { Kotzab and Teller (2003); } \\
\text { Lai, Su, Weng and Chen (2007); } \\
\text { Luo et al. (2006); } \\
\text { Padula and Dagnino (2007) }\end{array}$ & $\begin{array}{l}\text { Level of cooperation in local development process (Della Corte and Aria, 2016) } \\
\text { Intensity of cooperative relationships inside the industry (Della Corte and Aria, 2016) } \\
\text { Degree of willingness to collaborate or to compete (Wang and Krakover, 2008) }\end{array}$ & $\begin{array}{l}\text { Contextual } \\
\text { dimension }\end{array}$ \\
\hline $\begin{array}{l}\text { Past experience } \\
\text { in coopetition }\end{array}$ & \multirow{4}{*}{$\begin{array}{l}\text { Barretta (2008); } \\
\text { Cheng, Yeh and Tu (2008); } \\
\text { Gnyawali and Park (2009); } \\
\text { Grängsjö and Gummesson } \\
\text { (2006); } \\
\text { Osarenkhoe (2010) } \\
\text { Schiavone and Simoni (2011) }\end{array}$} & $\begin{array}{l}\text { Impact of relationships on inter-firm collaboration (Della Corte and Aria, 2016) } \\
\text { Prior experience of collaboration (Czernek and Czakon, 2016) }\end{array}$ & $\begin{array}{l}\text { Strategic } \\
\text { dimension }\end{array}$ \\
\hline $\begin{array}{l}\text { Participation in } \\
\text { existing networks }\end{array}$ & & $\begin{array}{l}\text { Number of companies with whom firms maintain relationships (Della Corte and Aria, 2016) } \\
\text { Embeddedness in social networks (Czernek and Czakon, 2016) } \\
\text { Embeddedness (Zach and Racherla 2011) }\end{array}$ & $\begin{array}{l}\text { Contextual } \\
\text { / Behavioral } \\
\text { dimension }\end{array}$ \\
\hline $\begin{array}{l}\text { Perceived } \\
\text { benefits }\end{array}$ & & $\begin{array}{l}\text { Mutual advantages (Della Corte and Aria, 2016) } \\
\text { Sharing informational platforms (Belleflamme and Neysen, 2006) } \\
\text { Exchange of information and ideas (Werner et al., 2015) } \\
\text { Knowledge and information sharing (Bagdoniene and Hopeniene, 2015) } \\
\text { Joint marketing activities to promote each other (Bagdoniene and Hopeniene, 2015) } \\
\text { Value creation and economies of scale (van der Zee and Vanneste, 2015) } \\
\text { Lifting the barriers of market entry (Belleflamme and Neysen, 2009) } \\
\text { Perceived benefits (Wang, 2008) } \\
\text { Strategic benefits (Chim-Miki and Batista-Canino, 2017) }\end{array}$ & $\begin{array}{l}\text { Strategic } \\
\text { dimension }\end{array}$ \\
\hline $\begin{array}{l}\text { Partner's } \\
\text { reputation }\end{array}$ & & $\begin{array}{l}\text { Perception of status, reciprocal, and confirmed exchange of information (Tortoriello et al., 2011) } \\
\text { Reputation in the network (Czakon and Czernek, 2016) } \\
\text { Legitimating by third party (Czernek and Czakon, 2016) }\end{array}$ & $\begin{array}{l}\text { Behavioral } \\
\text { dimension }\end{array}$ \\
\hline Trust in partners & \multirow{2}{*}{$\begin{array}{l}\text { Adomavičius and Lydeka (2007); } \\
\text { Barretta, (2008); } \\
\text { Eriksson (2008); } \\
\text { Gnyawali and Park (2009); } \\
\text { Osarenkhoe (2010) } \\
\text { Schiavone and Simoni (2011) }\end{array}$} & $\begin{array}{l}\text { Interpersonal trust (Tortoriello et al., 2011) } \\
\text { Number of trust relationships (Della Corte, Aria, 2016) } \\
\text { Trust-building mechanisms (Czakon, Czernek, 2016) }\end{array}$ & $\begin{array}{l}\text { Behavioral } \\
\text { dimension }\end{array}$ \\
\hline $\begin{array}{l}\text { Strategic } \\
\text { fit }\end{array}$ & & $\begin{array}{l}\text { Resource heterogeneity, resource overlap, resource locking (Zach and Racherla, 2011) } \\
\text { Access to missing resources, competencies, capabilities, and new markets (Bagdoniene and } \\
\text { Hopeniene, 2015) } \\
\text { Partner's intentions and motives analysis (Czernek and Czakon, 2016) } \\
\text { Partner's capabilities analysis (Czernek and Czakon, 2016) }\end{array}$ & $\begin{array}{l}\text { Managerial } \\
\text { dimension }\end{array}$ \\
\hline
\end{tabular}




\begin{tabular}{lll}
\hline Antecedents & General references* & Empirical investigation in tourism \\
\cline { 3 - 4 } & Partner heterogeneity (Zach and Racherla, 2011)
\end{tabular}

Notes: * General references identified in prior systematic literature reviews (Bengtsson and Raza-Ullah, 2016; Czakon et al., 2014; Dorn et al., 2016). 
Table 3. Questionnaire items.

\begin{tabular}{|c|c|c|c|}
\hline Statement & Antecedent & References & Code \\
\hline $\begin{array}{l}\text { To start collaboration with a competitor, it is enough } \\
\text { that I see benefits (e.g., resource access, cost } \\
\text { reduction opportunities, competitor control, gaining } \\
\text { advantage over rivals, effective strategy } \\
\text { implementation) }\end{array}$ & $\begin{array}{l}\text { Perceived } \\
\text { benefits }\end{array}$ & $\begin{array}{l}\text { Bouncken et al. (2015); } \\
\text { Damayanti et al. (2017; } \\
\text { Gnyawali and Park } \\
\text { (2009); }\end{array}$ & COOP_1 \\
\hline $\begin{array}{l}\text { To start collaboration with a competitor it is enough } \\
\text { that partners are strategically fit (including } \\
\text { convergent vision, common goals, and development } \\
\text { strategy) }\end{array}$ & $\begin{array}{l}\text { Strategic } \\
\text { fit }\end{array}$ & $\begin{array}{l}\text { Chin et al. (2008); van } \\
\text { der Zee and Vanneste, } \\
2015\end{array}$ & COOP_2 \\
\hline $\begin{array}{l}\text { The fact that my competitor is well recognized in } \\
\text { the local community* encourages me to collaborate } \\
\text { with her/him }\end{array}$ & $\begin{array}{l}\text { Partner's } \\
\text { reputation }\end{array}$ & $\begin{array}{l}\text { Bengtsson and Raza- } \\
\text { Ullah (2016); Czakon } \\
\text { and Czernek (2016) }\end{array}$ & COOP_3 \\
\hline $\begin{array}{l}\text { Me being member of a local partnering } \\
\text { network/organization encourages me to collaborate } \\
\text { with a competitor who is also a member }\end{array}$ & $\begin{array}{l}\text { Participation } \\
\text { in existing } \\
\text { networks }\end{array}$ & $\begin{array}{l}\text { Della Corte and Aria } \\
\text { (2016); Gnyawali et al. } \\
\text { (2006) }\end{array}$ & COOP_4 \\
\hline $\begin{array}{l}\text { My trust in a competitor encourages me to } \\
\text { collaborate with him/her }\end{array}$ & $\begin{array}{l}\text { Trust in } \\
\text { partners }\end{array}$ & $\begin{array}{l}\text { Chim-Miki and Batista- } \\
\text { Canino (2017); } \\
\text { Quintana-García and } \\
\text { Benavides-Velasco } \\
\text { (2004) }\end{array}$ & COOP_5 \\
\hline $\begin{array}{l}\text { The general collaboration willingness in my } \\
\text { community* encourages me to collaborate with my } \\
\text { competitor }\end{array}$ & $\begin{array}{l}\text { Cooperative } \\
\text { orientation }\end{array}$ & $\begin{array}{l}\text { Bouncken and Fredrich } \\
\text { (2016); Kylänen and } \\
\text { Rusko (2011) }\end{array}$ & COOP_6 \\
\hline $\begin{array}{l}\text { My prior experience of collaboration with } \\
\text { competitors encourages me to collaborate with other } \\
\text { competitors }\end{array}$ & $\begin{array}{l}\text { Past } \\
\text { experience } \\
\text { in coopetition }\end{array}$ & $\begin{array}{l}\text { Gnyawali et al. (2016); } \\
\text { van der Zee and } \\
\text { Vanneste (2015) }\end{array}$ & COOP_7 \\
\hline
\end{tabular}

Notes: * In our study, community is seen as covering the set of autonomous organizations focused on joint, longitudinal tourism planning run through a jointly implemented process of decision-making regarding the inter-organizational actions and behaviors aimed at the development and acceleration of development of a particular tourism domain. It is claimed that tourism communities are limited to one, specific tourism destination and, thus, have local rather than national or global scope (Wang and Krakover, 2008, p. 128). Tourism communities are limited to the tourism industry and take the specific, tourism-based communities of practice interested in knowledge distribution, sharing, and dissemination (Osarenkhoe, 2010). 


\section{Table 4}

Main characteristics of the sample of respondents.

\begin{tabular}{|c|c|c|c|c|c|}
\hline \multirow{2}{*}{\multicolumn{2}{|c|}{$\begin{array}{c}\text { Individual characteristics } \\
\text { Gender }\end{array}$}} & \multicolumn{4}{|c|}{ Organizational characteristics } \\
\hline & & \multicolumn{2}{|c|}{ Year of joining LTO* } & \multicolumn{2}{|c|}{$\begin{array}{l}\text { Voivodeship (administrative } \\
\text { area) }\end{array}$} \\
\hline Female & $62 \%$ & 2006 & $7.6 \%$ & Lubuskie & $1.6 \%$ \\
\hline Male & $38 \%$ & 2012 & $9.5 \%$ & Mazowieckie & $5.2 \%$ \\
\hline \multicolumn{2}{|c|}{ Age } & 2013 & $10.3 \%$ & Pomorskie & $33.6 \%$ \\
\hline under 20 & $1.1 \%$ & \multicolumn{2}{|c|}{ Year of establishment* } & Dolnośląskie & $3.0 \%$ \\
\hline $21-30$ & $7.6 \%$ & 2000 & $9 \%$ & Lubelskie & $6.8 \%$ \\
\hline $31-40$ & $37.9 \%$ & 2001 & $5.7 \%$ & Wielkopolskie & $12.8 \%$ \\
\hline $41-50$ & $31.9 \%$ & 2009 & $5.7 \%$ & Zachodniopomorskie & $4.1 \%$ \\
\hline \multirow[t]{9}{*}{ Jo over } & $21.5 \%$ & \multicolumn{2}{|c|}{ Family Business } & Małopolskie & $4.9 \%$ \\
\hline & & Yes & $54.9 \%$ & Warmińsko-mazurskie & $12.0 \%$ \\
\hline & & No & $45.1 \%$ & Podlaskie & $2.2 \%$ \\
\hline & & & & Opolskie & $1.6 \%$ \\
\hline & & & & Świętokrzyskie & $0.8 \%$ \\
\hline & & & & Śląskie & $4.3 \%$ \\
\hline & & & & Kujawsko-pomorskie & $6.3 \%$ \\
\hline & & & & Podkarpackie & $0.5 \%$ \\
\hline & & & & Łódzkie & $0.3 \%$ \\
\hline
\end{tabular}

Notes: * Due to space constraints, only the three the most frequent answers are shown. 
Table 5. Item statistics.

\begin{tabular}{lcccccccc}
\hline Antecedent & Code & Min & Max & Mean & SD & Variance & Skewness & Kurtosis \\
\hline Perceived benefits & COOP_1 & 1 & 5 & 3.79 & 1.132 & 1.281 & -0.754 & -0.193 \\
\hline Strategic fit & COOP_2 & 1 & 5 & 3.77 & 1.075 & 1.155 & -0.848 & 0.199 \\
\hline Partner's reputation & COOP_3 & 1 & 5 & 3.70 & 1.160 & 1.346 & -0.535 & -0.291 \\
\hline $\begin{array}{l}\text { Participation in existing } \\
\text { networks }\end{array}$ & COOP_4 & 1 & 5 & 3.60 & 1.232 & 1.517 & -0.696 & -0.425 \\
\hline $\begin{array}{l}\text { Trust in partners } \\
\text { Cooperative orientation }\end{array}$ & COOP_5 & 1 & 5 & 3.81 & 1.198 & 1.435 & -0.699 & 0.003 \\
\hline $\begin{array}{l}\text { Past experience in } \\
\text { coopetition }\end{array}$ & COOP_7 & 1 & 5 & 3.78 & 1.236 & 1.528 & -0.642 & -0.193 \\
\hline
\end{tabular}

Table 6. Correlations of items.

\begin{tabular}{|c|c|c|c|c|c|c|c|}
\hline \multirow{2}{*}{ Antecedent (code) } & COOP 1 & $\mathrm{COOP}_{-}$ & $\mathrm{COOP}_{3}$ & $\begin{array}{c}\mathrm{COOP}_{4} \\
{ }_{4}\end{array}$ & $\mathrm{COOP}_{5}$ & $\underset{6}{\mathrm{COOP}_{-}}$ & $\mathrm{COOP}_{7}$ \\
\hline & \multicolumn{7}{|c|}{ Spearman's rho } \\
\hline $\begin{array}{l}\text { Perceived benefits } \\
\text { (COOP_1) }\end{array}$ & 1.000 & & & & & & \\
\hline Strategic fit (COOP_2) & $0.539^{* *}$ & 1.000 & & & & & \\
\hline $\begin{array}{l}\text { Partner's reputation } \\
\text { (COOP_3) }\end{array}$ & $0.609^{* *}$ & $0.424^{* *}$ & 1.000 & & & & \\
\hline $\begin{array}{l}\text { Participation in existing } \\
\text { networks (COOP_4) }\end{array}$ & $0.534^{* *}$ & $0.501^{* *}$ & $0.635^{* *}$ & 1.000 & & & \\
\hline Trust in partners (COOP_5) & $0.548^{* *}$ & $0.474^{* *}$ & $0.631^{* *}$ & $0.599^{* * *}$ & 1.000 & & \\
\hline $\begin{array}{l}\text { Cooperative orientation } \\
\text { (COOP_6) }\end{array}$ & $0.495^{* *}$ & $0.450^{* * *}$ & $0.641^{* *}$ & $0.632^{* *}$ & $0.654^{* *}$ & 1.000 & \\
\hline $\begin{array}{l}\text { Past experience in } \\
\text { coopetition (COOP_7) }\end{array}$ & $0.480^{* *}$ & $0.439^{* *}$ & $0.587^{* *}$ & $0.573^{* *}$ & $0.653^{* *}$ & $0.700^{* *}$ & 1.000 \\
\hline
\end{tabular}

Notes: $* \mathrm{p}<0.10$; ** $\mathrm{p}<0.05 ; * * * \mathrm{p}<0.01$; **** $\mathrm{p}<0.001$ 
Table 7. Exploratory factor analysis for antecedents of coopetition-a three-factor solution.

\begin{tabular}{|c|c|c|c|c|c|c|c|}
\hline \multicolumn{5}{|c|}{ Model matrix ${ }^{a}$} & \multirow{3}{*}{$\begin{array}{c}\text { Cronb.'s } \\
\boldsymbol{\alpha}\end{array}$} & \multirow{3}{*}{ AVE } & \multirow{3}{*}{ CR } \\
\hline \multirow{2}{*}{$\begin{array}{l}\text { Latent } \\
\text { variables }\end{array}$} & \multirow{2}{*}{ Items } & \multicolumn{3}{|c|}{ Factor } & & & \\
\hline & & 1 & 2 & 3 & & & \\
\hline \multirow{3}{*}{$\begin{array}{l}\text { Coopetitive } \\
\text { mindset }\end{array}$} & Cooperative orientation & 0.932 & -0.077 & 0.006 & \multirow{3}{*}{0.876} & \multirow{3}{*}{0.658} & \multirow{3}{*}{0.849} \\
\hline & $\begin{array}{l}\text { Past experience in } \\
\text { coopetition }\end{array}$ & 0.837 & -0.002 & -0.004 & & & \\
\hline & Trust in partners & 0.636 & 0.161 & 0.070 & & & \\
\hline \multirow{2}{*}{$\begin{array}{l}\text { Strategic } \\
\text { rationale }\end{array}$} & Perceived benefits & -0.108 & 0.801 & 0.124 & \multirow{2}{*}{0.745} & \multirow{2}{*}{0.587} & \multirow{2}{*}{0.740} \\
\hline & Strategic fit & 0.145 & 0.730 & -0.126 & & & \\
\hline \multirow{2}{*}{$\begin{array}{l}\text { Rival's } \\
\text { recognition }\end{array}$} & Partner's reputation & 0.054 & -0.005 & 0.964 & \multirow[b]{2}{*}{0.777} & \multirow[b]{2}{*}{0.566} & \multirow[b]{2}{*}{0.698} \\
\hline & $\begin{array}{l}\text { Participation in existing } \\
\text { networks }\end{array}$ & 0.117 & 0.270 & 0.451 & & & \\
\hline
\end{tabular}

Notes: Factor loadings assigned to the extracted factors are shown in bold.

Factor extraction method-generalized least squares.

Rotation method-Promax with Kaiser's normalization.

${ }^{a}$ Rotation of convergence reached in six iterations. 
Table 8. Reliability and internal consistency of two-factor solution.

\begin{tabular}{|c|c|c|c|c|c|}
\hline \multirow{2}{*}{ Latent variable } & \multicolumn{2}{|c|}{$\begin{array}{c}\text { Internal consistency assessed using } \\
\text { Cronbach's } \alpha\end{array}$} & \multicolumn{3}{|c|}{$\begin{array}{c}\text { Convergent validity assessed using } \\
\text { AVE and CR }\end{array}$} \\
\hline & After EFA & Testing & $\begin{array}{c}\text { AVE } \\
(\text { value }>0.5)\end{array}$ & $\begin{array}{c}\text { CR } \\
(\text { value }>0.7)\end{array}$ & Testing \\
\hline Coopetitive mindset & 0.876 & $\mathrm{~S}$ & 0.710 & 0.880 & $\mathrm{~S}$ \\
\hline Strategic rationale & 0.745 & $S$ & 0.591 & 0.743 & $\mathrm{~S}$ \\
\hline Antecedents & 0.867 & $S$ & NA & NA & NA \\
\hline Items in total & 5 & NA & NA & NA & NA \\
\hline \multicolumn{6}{|c|}{ Discriminant validity assessed using covariations } \\
\hline \multirow{2}{*}{$\begin{array}{l}\text { Discriminant } \\
\text { validity }\end{array}$} & \multirow{2}{*}{$\begin{array}{c}\text { Factor } \\
\text { correlation }\end{array}$} & \multirow{2}{*}{$\begin{array}{l}\text { Correlation } \\
\text { squared }\end{array}$} & AVE mindset & AVE rationale & \multirow{2}{*}{ Testing } \\
\hline & & & \multicolumn{2}{|c|}{ AVEs $>\mathbf{r}^{2}$} & \\
\hline $\begin{array}{l}\text { Coopetitive mindset } \\
\& \text { Strategic rationale }\end{array}$ & 0.767 & 0.588 & $0.710>0.588$ & $0.591>0.588$ & $\mathrm{~S}$ \\
\hline
\end{tabular}

Notes: EFA - exploratory factor analysis. AVE - average variance extracted. CR - composite reliability. Hypothesis testing: $\mathrm{S}$ - supported; $\mathrm{R}$ - rejected; NA - not applicable. 
Table 9. Effect of coopetitive mindset and strategic rationale on tourism product complexity.

\begin{tabular}{lcc}
\hline \multicolumn{1}{c}{ Independent variable } & Model (TPC) coefficient & $\begin{array}{l}\text { Std. } \\
\text { error }\end{array}$ \\
\hline Main effects & $0.295 * * * *$ & \\
Coopetitive mindset & $0.180^{* * *}$ & 0.051 \\
Strategic rationale & & 0.061 \\
Company controls & 0.0019 & 0.0015 \\
Size & -0.0067 & 0.0989 \\
Family firm & $1.961 * * * *$ & 0.2397 \\
Constant & 0.2284 & \\
$\mathrm{R}^{2}$ & 0.2196 & \\
Adjusted $\mathrm{R}^{2}$ & 368 & \\
No. of firms & \\
Notes: $*<0.10 ; * * \mathrm{p}<0.05 ; * * * \mathrm{p}<0.01 ; * * * * \mathrm{p}<0.001$ & \\
TPC - complexity of tourism products. & & \\
\end{tabular}

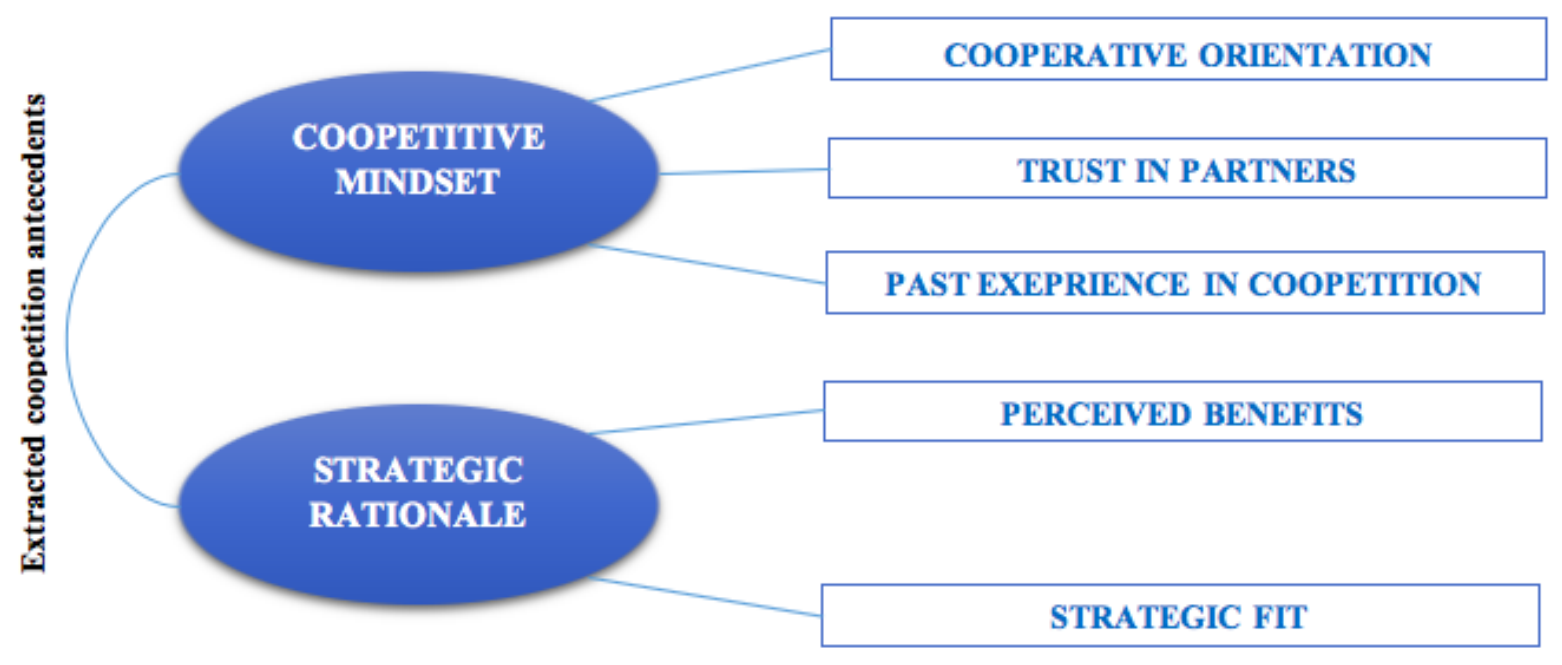

Fig. 1. Model of behavioral antecedents of coopetition in the tourism industry. 